\title{
Identification of ABCC8 as a contributory gene to impaired early- phase insulin secretion in NZO mice
}

\author{
Sofianos Andrikopoulos', Barbara C Fam ', Anita Holdsworth' ${ }^{2}$, Sherley Visinoni', \\ Zheng Ruan', Maria Stathopoulos', Anne W Thorburn', Christos N Joannides', \\ Michael Cancilla ${ }^{2}$, Lois Balmer ${ }^{3,4}$, Joseph Proietto' and Grant Morahan ${ }^{3}$ \\ ${ }^{1}$ Department of Medicine (AH), Austin Hospital, University of Melbourne, Level 7, Lance Townsend Building, \\ Studley Road, Heidelberg, Victoria 3084, Australia \\ ${ }^{2}$ Walter and Eliza Hall Institute of Medical Research, Parkville, 3010 Victoria, Australia \\ ${ }^{3}$ Harry Perkins Institute of Medical Research, Nedlands, Western Australia 6009, Australia \\ ${ }^{4}$ The School of Medical Sciences Edith Cowan University, Joondalup Western Australia 6027, Australia
}

Correspondence should be addressed to $S$ Andrikopoulos Email

sof@unimelb.edu.au

\begin{abstract}
Type 2 diabetes (T2D) is associated with defective insulin secretion, which in turn contributes to worsening glycaemic control and disease progression. The genetic cause(s) associated with impaired insulin secretion in T2D are not well elucidated. Here we used the polygenic New Zealand Obese (NZO) mouse model, which displays all the cardinal features of T2D including hyperglycaemia to identify genes associated with $\beta$-cell dysfunction. A genomewide scan identified a major quantitative trait locus (QTL) on chromosome 7 associated with defective glucose-mediated insulin secretion. Using congenic strains, the locus was narrowed to two candidate genes encoding the components of the KATP channel: Abcc8 (SUR1) and Kcnj11 (Kir6.2). The NZO Abcc8 allele was associated with a $\sim 211$ bp deletion in its transcript and reduced expression of SUR1. Transgenic NZO mice were generated that expressed the WT Abcc8/Kcnj11 genes and displayed significant improvements in early-phase glucosemediated insulin secretion and glucose tolerance, confirming Abcc 8 as a causative gene. Importantly, we showed that despite improving $\beta$-cell function in the NZO transgenic mice, there was no enhancement of insulin sensitivity or body weight. This study provides evidence for a role of $A b c c 8$ in early-phase glucose-mediated insulin secretion and validates this gene as a contributor to $\beta$-cell dysfunction in T2D.
\end{abstract}
Key Words
- insulin secretion
- glucose metabolism
- gene expression
- Islet cells

\section{Introduction}

Type 2 diabetes (T2D) is a complex and progressive metabolic disorder characterised by a chronic elevation of blood glucose levels. Although it is accepted that impaired insulin action is an initiating defect, hyperglycaemia only ensues when there is failure of the $\beta$-cell to secrete adequate amounts of insulin (Kahn 2003, Andrikopoulos 2010). Glucose is the predominant nutrient for insulin secretion, which enters the $\beta$-cell via the glucose transporter GLUT-2 and gets phosphorylated to glucose-6phosphate by the rate-determining enzyme, glucokinase (GK). This results in an increased flux through glycolysis and the tricarboxylic acid cycle causing a rise in the ATP:ADP ratio. The elevated ATP:ADP ratio closes the cell surface ATP-sensitive potassium (KATP) channels resulting in cell membrane depolarisation, opening of voltage-gated calcium channels, an influx of intracellular calcium and

Published by Bioscientifica Ltd 
finally insulin granule exocytosis. In this cascade of events, the KATP channel, composed of the outer binding subunit, SUR1 $(A b c c 8)$ and the inner core subunit Kir6.2 (Kcnj11), plays a pivotal role in connecting intracellular glucose metabolism to the exocytosis of insulincontaining secretory granules (Ashcroft 2005).

The secretory response is biphasic in nature with the early (first)-phase being transient and of a 2-5 min duration. The late (second)-phase is more prolonged and lasts the duration of the stimulus. In subjects with T2D, early-phase of secretion is absent whilst the late-phase is diminished (Halter et al. 1985). Despite much effort, the mechanism(s) for the progressive impairment of the secretory response in T2D is unknown (Cheng et al. 2013). Recent large genome-wide association studies have identified a number of genes linked with beta cell dysfunction in T2D including TCF7L2, CDKAL1, HHEX, SLC30A8, CDKN2A/B and IGB2BP2 (Saxena et al. 2007, Sladek et al. 2007). However, it is not clear how these genes affect insulin secretion, although TCF7L2 has been linked to impaired early-phase secretion (Palmer et al. 2008). Thus, while progress has been made in understanding environmental and genetic factors associated with $\beta$-cell dysfunction in T2D, further work is required to provide a more complete mechanism.

Most spontaneous rodent models of obesity and T2D (e.g. Zucker diabetic fatty ( $f a / f a)$ rat, and $o b / o b$ and $d b / d b$ on the $\mathrm{C} 57 \mathrm{BL} / \mathrm{Ks}$ background) have monogenic defects as the primary cause of their phenotype, which is not the case for the majority of individuals with T2D, a polygenic disease. Thus, polygenic rodent models are more suitable to define and characterise the numerous genes that could be considered potential candidates. One such model is the New Zealand Obese (NZO) mouse, a well-established model of obesity and glucose intolerance, exhibiting several concomitant phenotypes including fasting hyperglycaemia, hyperinsulinaemia and hepatic and peripheral insulin resistance (Fam \& Andrikopoulos 2007). Importantly, these mice have distinguishable defects in glucosemediated insulin secretion when tested using isolated islets in vitro(Larkins \& Martin 1972, Veroni et al. 1991). In addition, the presence of these disturbances in young NZO mice (4-5 weeks of age) suggested that they were an early perturbation in the syndrome and that their cause could be genetic in origin (Veroni et al. 1991).

In attempts to identify genes contributing to T2D, a number of studies have utilised the NZO mouse (Leiter et al. 1998, Kluge et al. 2000, Plum et al. 2000, 2002, Kluth et al. 2011, Reifsnyder et al. 2000, Taylor et al. 2001, Reifsnyder \& Leiter 2002, Giesen et al. 2003, Scherneck et al. 2009, Vogel et al. 2009). Whilst these studies have reported linkage to obesity and hyperglycaemia, they have not yet identified any causative genes, nor has any locus been described which specifically affects insulin secretion. The present study was undertaken to determine the genetic cause(s) underlying impaired insulin secretion in the NZO mouse.

\section{Materials and methods}

\section{Animal source and maintenance}

C57BL/6J (B6) (Wong et al. 2010) and NZO/Wehi mice were purchased from the Walter and Eliza Hall Institute (Kew, Victoria, Australia). For genetic studies, we mated NZO to B6 mice and backcrossed F1 mice to the B6 parental strain to generate backcross (BC) mice for initial testing. Congenic mice were generated by backcrossing to the B6 strain for at least ten generations. Mice from this mating that were heterozygous in the region of interest were selected to commence brother-sister mating to produce five congenic lines (B6.NZO-7A, B6.NZO-7B, B6.NZO-7C, B6.NZO-7D and B6.NZO-7G), each containing different portions of the NZO chromosome seven region on the $\mathrm{B} 6$ background. Homozygotes of each line were selected to maintain the subsequent congenic strain.

Mice consumed a standard chow diet ad libitum containing $(\mathrm{w} / \mathrm{w}) 3 \%$ fat, $20 \%$ protein and $77 \%$ carbohydrate (Barastoc, Pakenham, Victoria, Australia). Artificial lighting was maintained on a 12-h day/night cycle and room temperature kept at $22^{\circ} \mathrm{C}$. Ethics approval was obtained from Melbourne Health and Austin Health Animal Ethics Committees and all experimental procedures were carried out in accordance with guidelines of these committees.

\section{Genotyping}

Genomic DNA was prepared from liver samples or tail snips using either a proteinase $\mathrm{K}$ extraction or a sodium hydroxide lysis extraction protocol (Morahan et al. 1989). Mice were genotyped by amplification of simple sequence length polymorphism (SSLP) markers selected from the Whitehead Institute SSLP library (http://www.genome.wi. mit.edu/) on the basis of their position on the genetic map. A $10 \mathrm{cM}$-dense genome scan was performed using 150 SSLPs. For fine-mapping studies, closely spaced markers spanning chromosomal regions of interest were also used (Supplementary Table 1, see section on supplementary data given at the end of this article).

Published by Bioscientifica Ltd. 


\section{Sequence analysis and generation of Abbc8 transgenic mice}

The murine $A b c c 8$ and $K c n j 11$ genomic loci were characterised from several bacterial artificial chromosome (BAC) clones that were isolated from an RPCI-23 female B6 BAC library (Morahan et al. 1989) after screening using radioactively labelled $\left[\gamma_{-}{ }^{32} \mathrm{P}\right]$ oligonucleotide probes containing Abcc8 and Kcnj11 coding sequences. One of the clones which contained the full coding regions of $A b c c 8$ and Kcnj11 was selected for partial sequencing and for generation of transgenic mice using the bm1 strains as previously described (Lander \& Kruglyak 1995). Transgenic mice were identified by screening for sequences derived from the BAC ends. These transgenic mice were subsequently backcrossed to NZO for at least 12 generations, selecting at each generation for retention of the B6 Abcc8 BAC before studies were performed.

\section{Genome wide scan: LOD score analysis}

The phenotypic and genotypic data were used for quantitative trait locus (QTL) analysis to assess whether a particular chromosomal region co-segregated with the phenotype measured. Only markers with valid genotypes for at least $90 \%$ of mice were included for further analysis. This procedure and single trait multiple interval mapping linkage analyses were performed using the QGENE package (Lander \& Kruglyak 1995). Linkage results were expressed as logarithm (base 10) of odds (LOD) scores. For autosomes, a LOD score $>3.3$ in $\mathrm{BC}$ mice may be considered significant evidence of linkage, at the 0.05 level by using the 'free model' in which the degree of dominance is estimated from the data ( $2 \mathrm{df}$ ) (Lander \& Kruglyak 1995). In addition, comparisons were performed comparing the upper and lower quartile responders using contingency $\chi^{2}$ analyses. The $\chi^{2}$ values were converted to LOD scores as described (Lander \& Kruglyak 1995).

\section{Tissue homogenisation}

Pancreata were homogenised in $2 \mathrm{ml}$ of ice-cold lysis buffer (0.24 $\mathrm{g}$ Tris, $0.029 \mathrm{~g}$ EDTA and $8.56 \mathrm{~g}$ sucrose in $100 \mathrm{ml}$ MilliQ water, pH 7.4) using an Ultra-Turrax homogeniser (Janke \& Kunkel, Staufen, Germany). Homogenates were centrifuged at $300 \boldsymbol{g}$ for $5 \mathrm{~min}$ at $4{ }^{\circ} \mathrm{C}$ to remove cell debris. Supernatants were collected and centrifuged at $100000 \boldsymbol{g}$ at $4{ }^{\circ} \mathrm{C}$ for $30 \mathrm{~min}$. Pellets were resuspended in ice-cold PBS containing 2\% Triton X-100 and $1.5 \mathrm{mM}$ pefabloc. Pellet protein concentrations were determined using the Bradford protein assay technique.

\section{Western blot analysis}

Western blotting was performed to determine protein expression levels of SUR1 and Kir6.2 in the pellet fraction of homogenised pancreata as previously described (Kooptiwut et al. 2005). Protein was loaded onto a $10 \%$ resolving gel (Kir6.2) or a 7.5\% resolving gel (SUR1) and immunodetected using their respective specific primary antibodies from Santa Cruz Biotechnology, Inc. at a 1:500 dilution overnight at $4{ }^{\circ} \mathrm{C}$; anti-Kir6.2 (H-55) (sc-20809) and anti-SUR1 (C-16) (sc-5789) antibodies respectively. All blots were incubated with a swine anti-rabbit IgG antibody conjugated to HRP secondary (DakoCytometrics, Glostrup, Denmark) at 1:2500 dilution for $1 \mathrm{~h}$ at room temperature. Protein bands were visualised on hyperfilm by the enhanced chemiluminescence system and band density assessed using Bio-Rad GS-710 calibrated imaging densitometer and quantified using the Quantity One (version 4.1) Software (Bio-Rad Laboratories Pty Ltd, Hercules, CA, USA).

\section{Intravenous tolerance tests to glucose and non-glucose secretagogues}

IVTT were performed as previously described (Veroni et al. 1991, Andrikopoulos et al. 2005). Insulin secretion was determined in response to the following stimuli; glucose $(1 \mathrm{~g} / \mathrm{kg})$, tolbutamide $(40 \mathrm{mg} / \mathrm{kg})$ and arginine $(2 \mathrm{~g} / \mathrm{kg})$.

\section{Intraperitoneal glucose tolerance test (IPGTT)}

IPGTTs were performed as previously described (Andrikopoulos et al. 2008, Visinoni et al. 2008). Briefly, after an overnight fast, a bolus of glucose $(1 \mathrm{~g} / \mathrm{kg})$ was injected intraperitoneally and blood sampled for plasma glucose and insulin analyses.

\section{Insulin tolerance test}

ITTs were performed as previously described (Lamont et al. 2006). Mice were administered with $0.5 \mathrm{IU} / \mathrm{kg}$ of Actrapid insulin intraperitoneally and glucose measurements from the tail were taken at 15,30, 45 and $60 \mathrm{~min}$.

\section{Measurement of circulating glucose and insulin levels}

The glucose oxidase method was used to determine plasma glucose using an Analox GM7 glucose analyser (Helena Laboratories, Mount Waverley, Victoria, Australia). Plasma insulin was measured using a commercially available radioimmunoassay utilising a rat-specific insulin antibody (Merck Millipore, Bayswater Victoria, Australia).

Published by Bioscientifica Ltd 


\section{Islet isolation and CDNA preparation}

Islets were isolated and incubated for insulin secretion studies as previously described (Kooptiwut et al. 2005, Zraika, et al. 2006). Islets were prepared for cDNA synthesis and subsequent mRNA analysis using the method as previously described (Aston-Mourney et al. 2007). Total RNA $(2 \mu \mathrm{g})$ was reverse transcribed using the Promega Reverse Transcription System kit with random primers (Promega Corporation) and any contaminating DNA removed by treatment with DNaseI (RNase-free; Ambion).

\section{Statistical analysis}

Data are expressed as mean \pm s.E.M. Area under the curve (AUC) was calculated using the trapezoidal rule. General Linear Model ANOVA (GLM ANOVA) with a Tukey's post hoc test was used to determine significant differences in plasma glucose and insulin levels between strains in response to the IVTT, IPGTT and ITT repeated measures. Two-tailed, unpaired student's $t$-test for parametric data analysis was used to compare between strains for mRNA expression, western blot and insulin content analysis. A $P$ value $\leq 0.05$ was considered statistically significant.

\section{Results}

\section{Insulin secretory responses in NZO mice}

We confirmed that NZO mice had a mild defect in insulin secretion in response to tolbutamide but not arginine at the early age of 4 weeks (Supplementary Fig. 1, see section on supplementary data given at the end of this article). At 4 weeks of age, NZO mice were heavier but had normal fasting plasma glucose and insulin levels compared with B6 (Supplementary Table 2). At 10 weeks of age, the defect in insulin secretion in NZO was more pronounced following glucose (Fig. 1A) and tolbutamide (Fig. 1B) administration, but not arginine (Fig. 1C) compared with B6. This is reflected in the area under the curve (AUC) (Fig. 1D) and suggests a defect at or upstream of the KATP channel. Pancreatic insulin content was not different in 4-week-old mice (NZO: $2.57 \pm 0.53$ vs B6: $1.73 \pm 0.27 \mathrm{ng} / \mathrm{mg}$ protein, $n=5 ; P=0.09$ ) but was significantly higher in NZO compared with B6 at 10 weeks of age (NZO: $5.66 \pm 0.55$ vs $\mathrm{B} 6: 2.83 \pm 0.41 \mathrm{ng} / \mathrm{mg}$ protein, $n=5 P=0.003)$, suggesting a functional defect in secretion. At 10 weeks of age, NZO mice were obese, hyperglycaemic and hyperinsulinaemic compared with B6 (Table 1).

\section{Mapping the defective insulin secretion locus in NZO mice}

In order to define the genetic basis of this defect, QTL mapping was performed on 130 backcrossed mice, comparing segregation of alleles in the lower and upper quartiles of insulin secretion, where the upper quartile contained mice with responses within the B6 range (high insulin levels) and the lower quartile contained mice which responded similarly to NZO mice (low insulin levels). Contingency $\chi^{2}$ values were calculated and used to derive LOD scores. Linkage was found to a region on chromosome 7 at marker D7Mit176 located around $26 \mathrm{cM}$ from the centromere (Fig. 2A and B). Fine mapping in the linked region in the first cohort of backcross mice mapped the locus to a $\sim 5 \mathrm{cM}$ interval between the markers D7Mit158 and D7Mit82 (Fig. 2B) with a LOD score of 13.1. Linkage was confirmed $(\mathrm{LOD}=5.7)$ in an independently generated cohort of 99 backcross mice, and an analysis of the pooled backcross mice using a multipoint method confirmed this linkage (not shown). The locus on chromosome 7 was denoted as dis1, for defective insulin secretion.
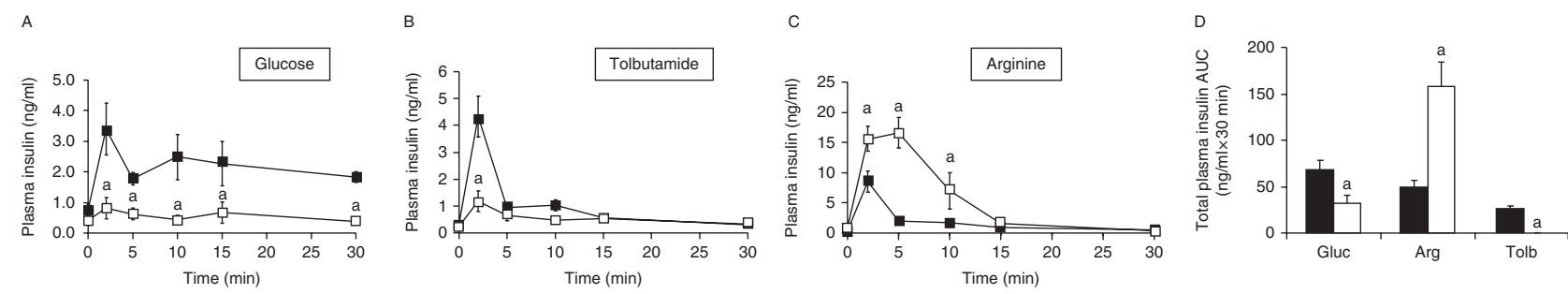

Figure 1

Plasma insulin secretory response following an intravenous tolerance test (IVTT) in 10 week old B6 (black squares) and NZO (white squares) mice to (A) glucose (B) tolbutamide (C) arginine (D) Total area under the curve (AUC)

for insulin responses to the three secretagogues glucose (Gluc), arginine (Arg) and tolbutamide (Tolb). Values are presented as mean \pm s.E.M. $(n=8-10) .{ }^{\mathrm{a}} P<0.05$ vs $\mathrm{B} 6$.

Published by Bioscientifica Ltd. 
Table 1 Body weight, adiposity levels (corrected for body weight) and baseline characteristics of 10-week-old C57BL/6 (B6), NZO and NZO transgenic (NZO tg) mice.

\begin{tabular}{|c|c|c|c|c|}
\hline & & B6 & NZO & NZO tg \\
\hline \multirow{7}{*}{ Males } & Body weight (g) & $22.4 \pm 0.3$ & $39.2 \pm 0.4^{*}$ & $40.3 \pm 1.2^{*}$ \\
\hline & Subcut mass $(\mathrm{mg} / \mathrm{g})$ & $2.2 \pm 0.2$ & $7.8 \pm 0.6^{*}$ & $6.9 \pm 0.6 *$ \\
\hline & Infrarenal mass $(\mathrm{mg} / \mathrm{g})$ & $0.5 \pm 0.1$ & $4.7 \pm 0.7 *$ & $5.4 \pm 0.6^{*}$ \\
\hline & Gonadal $(\mathrm{mg} / \mathrm{g})$ & $3.0 \pm 0.3$ & $12.5 \pm 1.0^{*}$ & $13.1 \pm 1.8^{*}$ \\
\hline & BAT $(\mathrm{mg} / \mathrm{g})$ & $2.3 \pm 0.1$ & $5.3 \pm 0.3 *$ & $4.8 \pm 1.1 *$ \\
\hline & Plasma glucose $(\mathrm{mmol} / \mathrm{l})$ & $6.89 \pm 0.44$ & $12.68 \pm 1.23^{\dagger}$ & $13.5 \pm 0.9 *$ \\
\hline & Plasma insulin (ng/ml) & $0.28 \pm 0.04$ & $0.48 \pm 0.05^{\dagger}$ & $0.93 \pm 0.19^{*, \neq}$ \\
\hline \multirow[t]{7}{*}{ Females } & Body weight $(\mathrm{g})$ & $17.3 \pm 0.4$ & $30.7 \pm 0.5^{\star}$ & $30.2 \pm 1.1 *$ \\
\hline & Subcut mass $(\mathrm{mg} / \mathrm{g})$ & $2.9 \pm 1.0$ & $7.6 \pm 0.4 *$ & $8.4 \pm 1.2 *$ \\
\hline & Infrarenal mass $(\mathrm{mg} / \mathrm{g})$ & $0.4 \pm 0.1$ & $3.1 \pm 0.2^{\dagger}$ & $3.2 \pm 0.7^{\dagger}$ \\
\hline & Gonadal $(\mathrm{mg} / \mathrm{g})$ & $0.9 \pm 0.2$ & $6.6 \pm 0.7^{\dagger}$ & $4.5 \pm 0.8^{\dagger}$ \\
\hline & BAT $(\mathrm{mg} / \mathrm{g})$ & $3.1 \pm 0.3$ & $5.2 \pm 0.3^{\dagger}$ & $2.9 \pm 0.4$ \\
\hline & Plasma glucose $(\mathrm{mmol} / \mathrm{l})$ & $6.56 \pm 0.45$ & $9.47 \pm 0.81 *$ & $11.3 \pm 0.9 *$ \\
\hline & Plasma insulin ( $\mathrm{ng} / \mathrm{ml})$ & $0.36 \pm 0.05$ & $0.81 \pm 0.35^{*}$ & $1.86 \pm 0.49^{\dagger, \neq}$ \\
\hline
\end{tabular}

Values are presented as mean \pm s.E.M. $(n=10) .{ }^{*} P<0.05,{ }^{\dagger} P<0.005$ vs B6, ${ }^{\ddagger} P<0.05$ vs NZO.

\section{dis 1 congenic strains show defective insulin secretion}

In order to fine-map the dis1 locus, and to investigate its functional effects in detail, we produced congenic mice by introgressing the relevant NZO-derived region onto the B6 genetic background. After ten generations of backcrossing, the B6.NZO- ${ }^{\text {D7Mit270-D7Mit146 }}$ congenic strain (hereafter referred to as B6.NZO-7A) was derived (Fig. 3A). The B6.NZO-7A was used to establish sub-congenic strains that had smaller overlapping intervals, which were defined with a series of novel SSLP markers (designated as D7Mor\#, see Supplementary Table 1, see section on supplementary data given at the end of this article). These strains were designated B6.NZO-7B, B6.NZO-7C, B6.NZO-7D, B6.NZO$7 \mathrm{G}$ (see Fig. 3A for details). When challenged with glucose, B6.NZO 7A, 7B and 7D lines had no significant differences in plasma glucose levels (Fig. 3B), but displayed reduced levels of plasma insulin compared with B6, similar to that

A
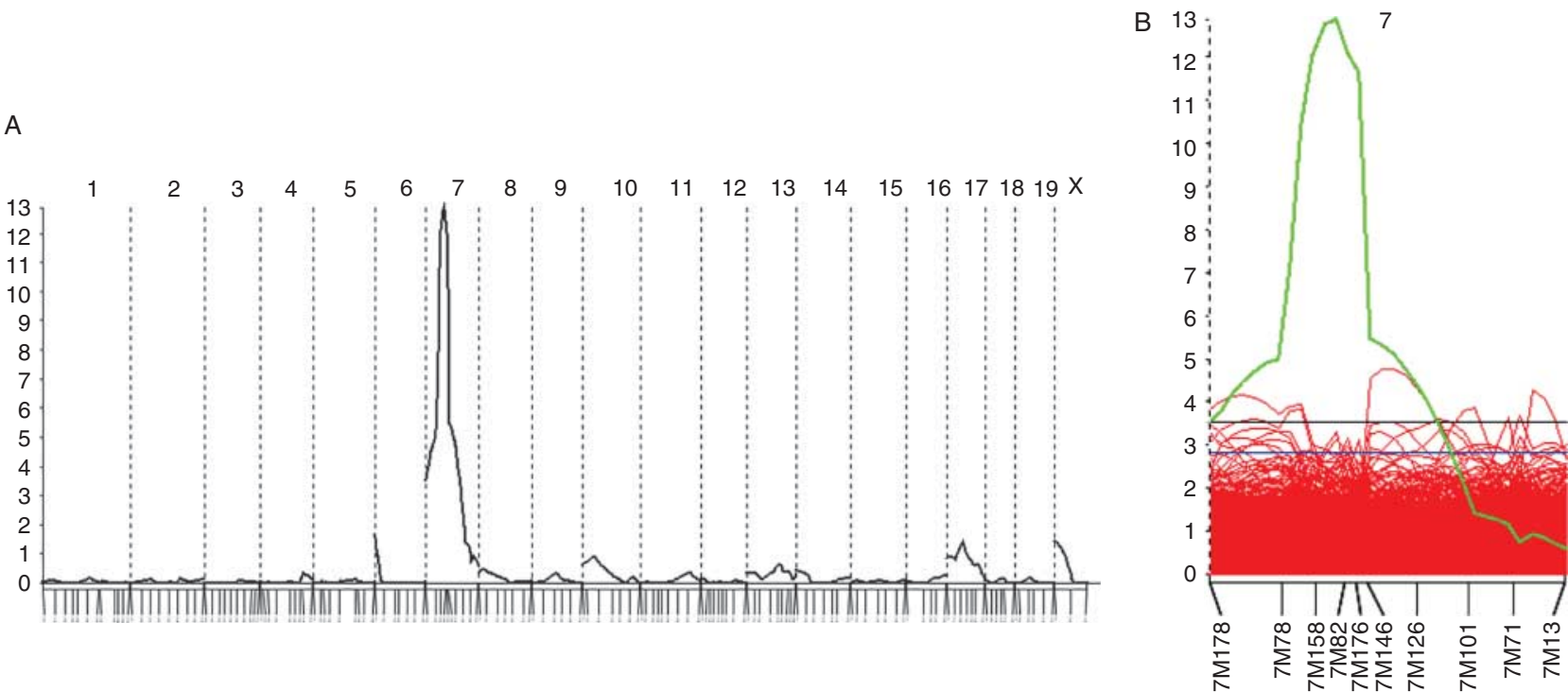

Figure 2

Mapping of the dis1 locus. (A) Genome-wide scans were performed on 130 backcross mice, using normalized data. Linkage was found to a region on chromosome 7 with a LOD score of 13.1 at marker D7Mit176 located around $26 \mathrm{cM}$ from the centromere (B) Multipoint mapping of Dis1 with
$0.5 \mathrm{cM}$ intervals (green lines) mapped the locus to a $<5 \mathrm{cM}$ interval between the markers D7Mit158 and D7Mit82 on chromosome 7. The data were also permuted and linkage calculated 10000 times (red lines).

Published by Bioscientifica Ltd. 
A
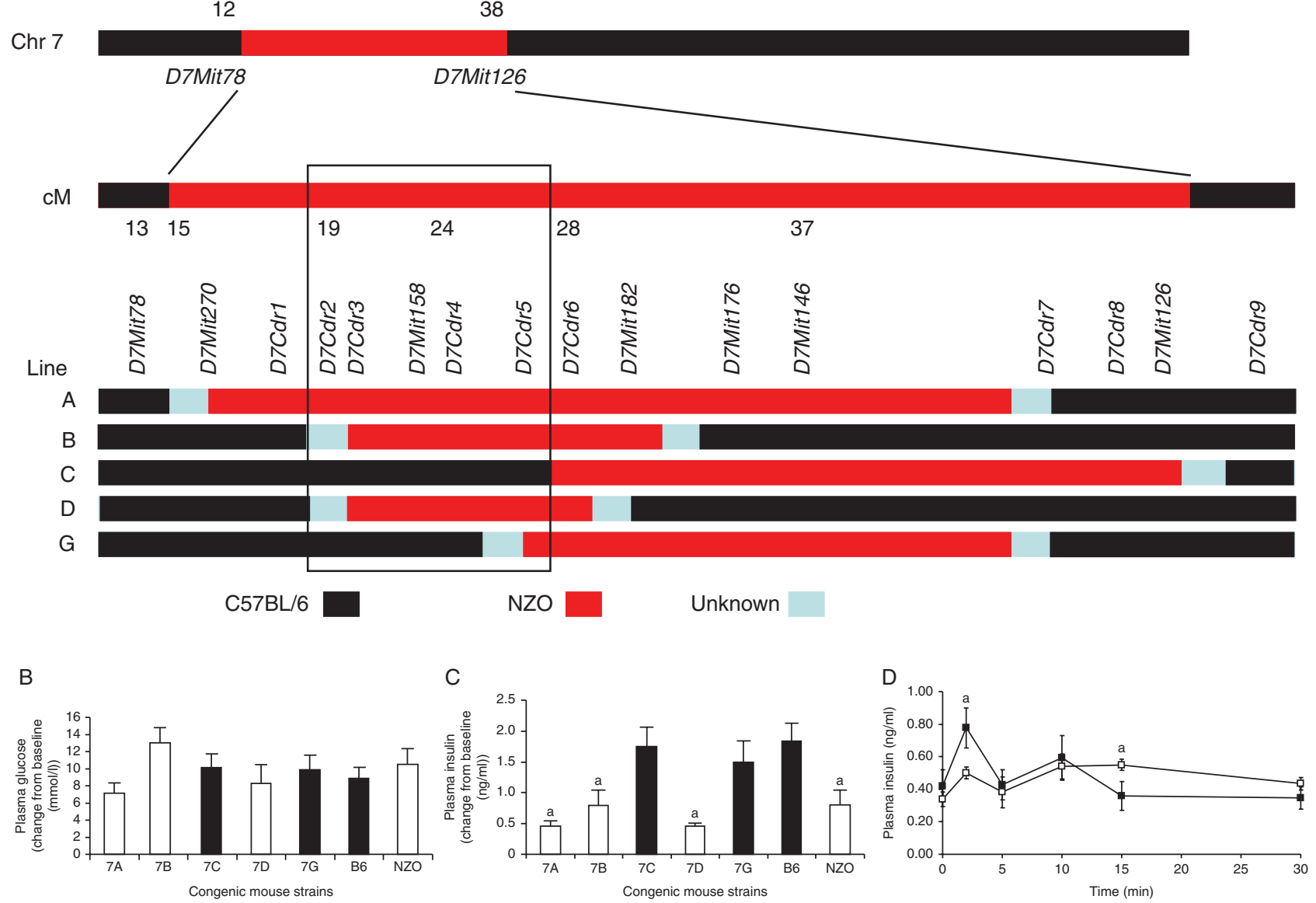

Figure 3

(A) Boundary markers for each congenic strain and region of interest boxed (B) Change in plasma glucose levels after a 20 min glucose tolerance test in the congenic strains, B6 and NZO mice. Black bars indicate a B6-like response, while white bars indicate a NZO-like response. (C) Change in plasma insulin levels after a 20 min glucose tolerance test in congenic

of the NZO parent (Fig. 3C). Conversely, B6.NZO-7C and $7 \mathrm{G}$ displayed the same ability to secrete insulin as the $\mathrm{B} 6$ parents. These results confirmed the mapping of dis1 to chromosome 7 and localised it to a $\sim 2.5 \mathrm{Mb}$ region between D7Mor13 and D7Mor10.

This region contains strong candidate genes encoding the components of the KATP channel $A b c c 8$ (SUR1) and Kcnj11 (Kir6.2). To test the NZO KATP channel, we assessed insulin secretion in response to tolbutamide. The B6.NZO-7A congenic mice had a reduced insulin response compared with B6.NZO-7C congenic mice (Fig. 3D, AUC: $2.16 \pm 0.24$ vs $3.30 \pm 0.43 \mathrm{ng} / \mathrm{ml} \times 5 \mathrm{~min}$ $n=5, P<0.05$ respectively). This is consistent with the hypothesis that defects in the KATP channel may be responsible for the defective insulin secretory response seen in the NZO mouse. strains, B6 and NZO mice. Black bars indicate a B6-like response, while white bars indicate a NZO-like response. (D) Insulin secretion in response to an intravenous tolbutamide bolus in B6.NZO-7A ( $\square$ ) and B6.NZO-7C ( $\square$ ) congenic mice. Values are presented as mean \pm s. E.M. $n=4-8 .{ }^{a} P<0.05$.

\section{Characterisation of the Abcc8 and Kcnj11 genes as candidates for dis1}

In order to characterise these candidate genes, we undertook direct sequencing of the NZO and B6 alleles and compared them with the already published $129 \mathrm{~T} 2$ sequence (37). There were no amino acid replacing changes in the Kcnj11 gene or changes in its promoter (data not shown). In contrast, there was striking complexity in the $A b c c 8$ gene and its promoter (Supplementary Fig. 2 , see section on supplementary data given at the end of this article). A region of $\sim 600 \mathrm{bp}$ of the $A b c c 8$ promoter showed several changes between NZO and the non-obese strains, B6 and 129T2 (Funkat, et al. 2004). While there was only one apparent nucleotide substitution among these strains, there were a total of six insertion/deletion events

Published by Bioscientifica Ltd 
A
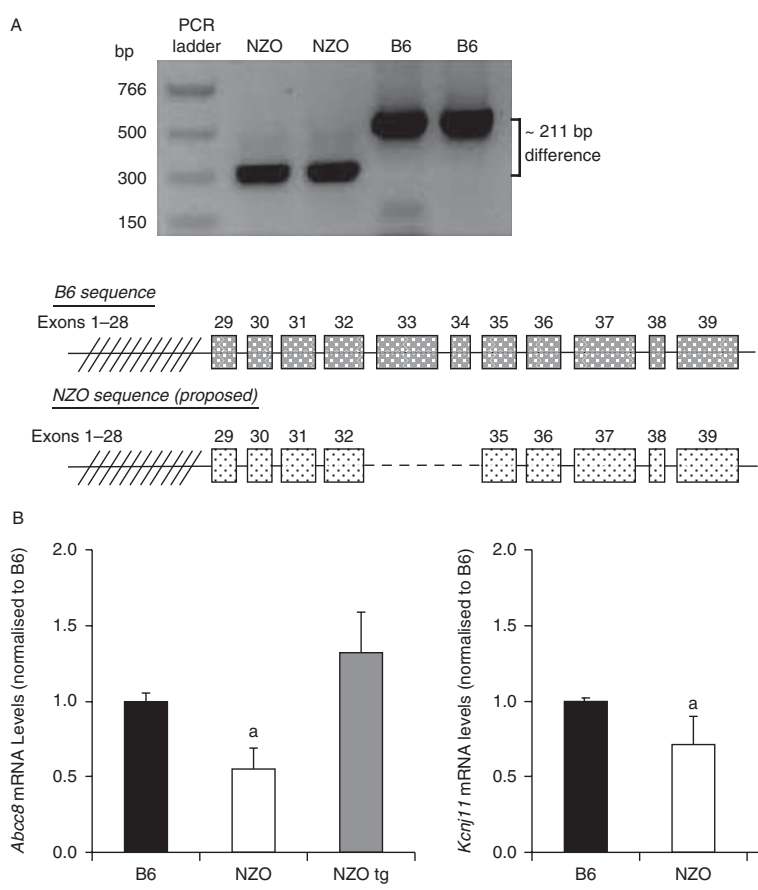
NZO sequence (proposed)
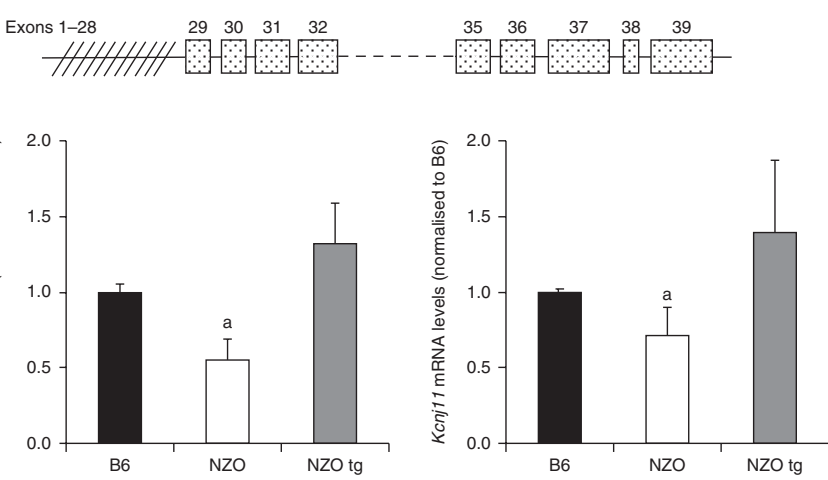

Figure 4

(A) PCR of $A b c c 8$ coding region from islets showing $211 \mathrm{bp}$ deletion in NZO mice compared with B6 mice (B) mRNA expression of $A b c c 8$ and Kcnj11 transcripts in B6, NZO and NZO transgenic islets as determined by Real Time PCR relative to $18 \mathrm{~S}$ and expressed as a fold change from $\mathrm{B} 6$. Values are presented as mean \pm s. E.M. $n=4-8$. ${ }^{\mathrm{a}} P<0.05$ vs B6.

affecting these three alleles. These events may have arisen as a consequence of the pyrimidine-rich sequence composition in the region.

$A b c c 8$ cDNA from NZO islets was also cloned and sequenced. Relative to the published sequences, there was a deletion of $\sim 211 \mathrm{bp}$ that corresponded to the removal of exons 33 and 34 from the NZO cDNA (Fig. 4A). The reason for the absence of these exons from the cDNA was unclear as both were present in the NZO genomic DNA with no changes to their flanking sequences (Supplementary Fig. 4, see section on supplementary data given at the end of this article). However, it appears to be a retroviral insertion between these exons as they are flanked by long terminal repeats (Supplementary Fig. 4). Amplification of the intron showed a $\sim 5 \mathrm{~kb}$ insertion into intron 34 of the NZO $A b c c 8$ gene (Supplementary Fig. 3). Quantitation of mRNA expression levels showed that the absence of exons 34 and 35 was associated with a $50 \%$ reduction in $\mathrm{Abcc8}$ expression levels in NZO mice compared with $\mathrm{B} 6$ mice (Fig. 4B). There was also a smaller (30\%) but significant decrease in Kcnj11 gene expression in islets of NZO compared with B6 mice (Fig. 4B).
In order to test whether the splice variant affected protein levels, immunoblot analysis was performed using whole pancreata from $\mathrm{B} 6$ and NZO mice. The data show that there was significantly less SUR1 protein (38\%) in the 10week-old NZO mice compared with the B6 mice, and this difference was also detected in 4-week-old mice (Supplementary Fig. 5). Interestingly, there was no significant difference in Kir6.2 levels at either age and this served as the internal control (Supplementary Fig. 5). Together, these data suggest that the $211 \mathrm{bp}$ deletion in $A b c c 8$ is associated with reduced gene and protein levels in NZO mice.

\section{Production of Abcc8 transgenic mice}

To determine whether the decrease in insulin secretion associated with these genes could be reversed, transgenic mice expressing the $\mathrm{B} 6 \mathrm{Abcc8} / \mathrm{Kir} 6.2$ genes on the NZO background were produced (referred to herein as NZO transgenic mice). The $A b c c 8$ and $K c n j 11$ genes were isolated on a single clone from a B6 BAC library. This clone was used to generate transgenic mice as described in the Methods section. Figure 4B illustrates that mRNA expression of $A b c c 8$ was significantly higher in the NZO transgenic compared with NZO control mice but was not different from B6. Similarly Kcnj11 expression tended to be higher in the NZO transgenic mice and not different from B6 (Fig. 4B). This indicates that the presence of the functional $A b c c 8 / K c n j 11$ genes in the pancreata of NZO transgenic mice caused a significant improvement in expression of both channel subunits.

Table 1 illustrates the baseline characterisation of the NZO transgenic mice compared with the two control lines, NZO and B6. Body weights and adiposity levels (as measured by white adipose tissue mass) of both the 10-week-old male and female NZO transgenic mice were not significantly different from the NZO control mice but were significantly higher than the $\mathrm{B} 6$ mice of both sexes $(P<0.05)$. Fasting plasma glucose levels were not different from the NZO mice in either sex. Interestingly, fasting plasma insulin levels were significantly higher in the NZO transgenic mice compared with both the $\mathrm{B} 6$ and NZO mice $(P<0.05)$. Therefore, replacement of the functional $A b c c 8 / K c n j 11$ gene in NZO transgenic mice significantly affected basal insulin levels but not overall glycaemia or obesity.

\section{Insulin secretory response in NZO transgenic mice}

To determine whether complementing the defective Abcc8/Kcnj11 gene with the functional B6 gene could

Published by Bioscientifica Ltd 
A
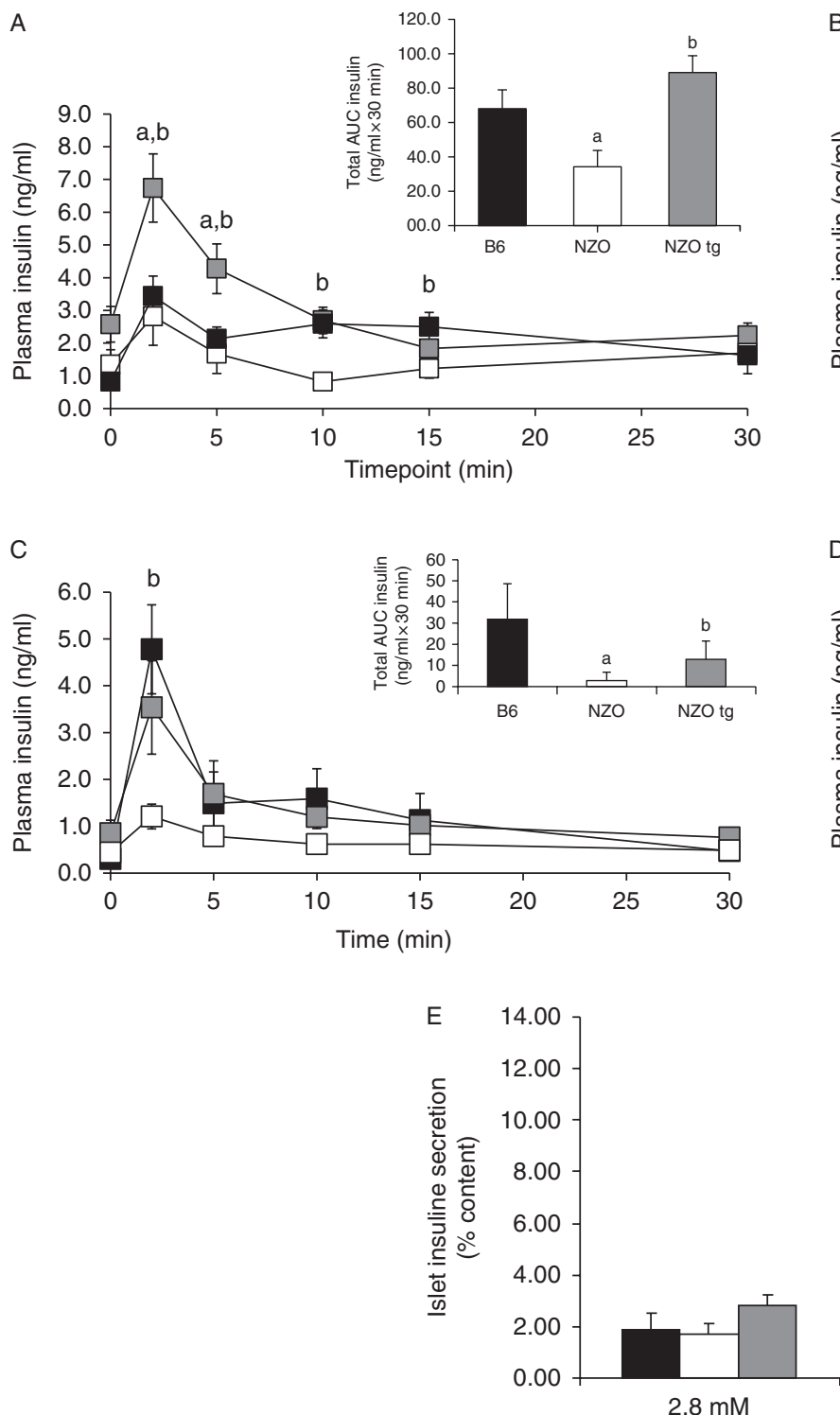

B

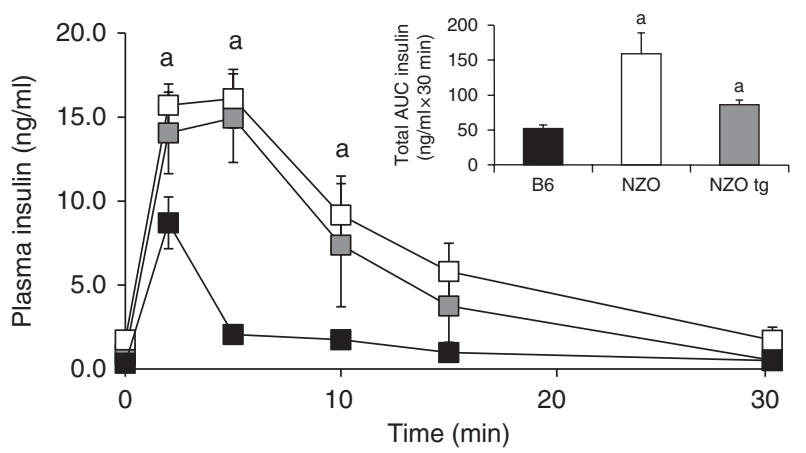

D
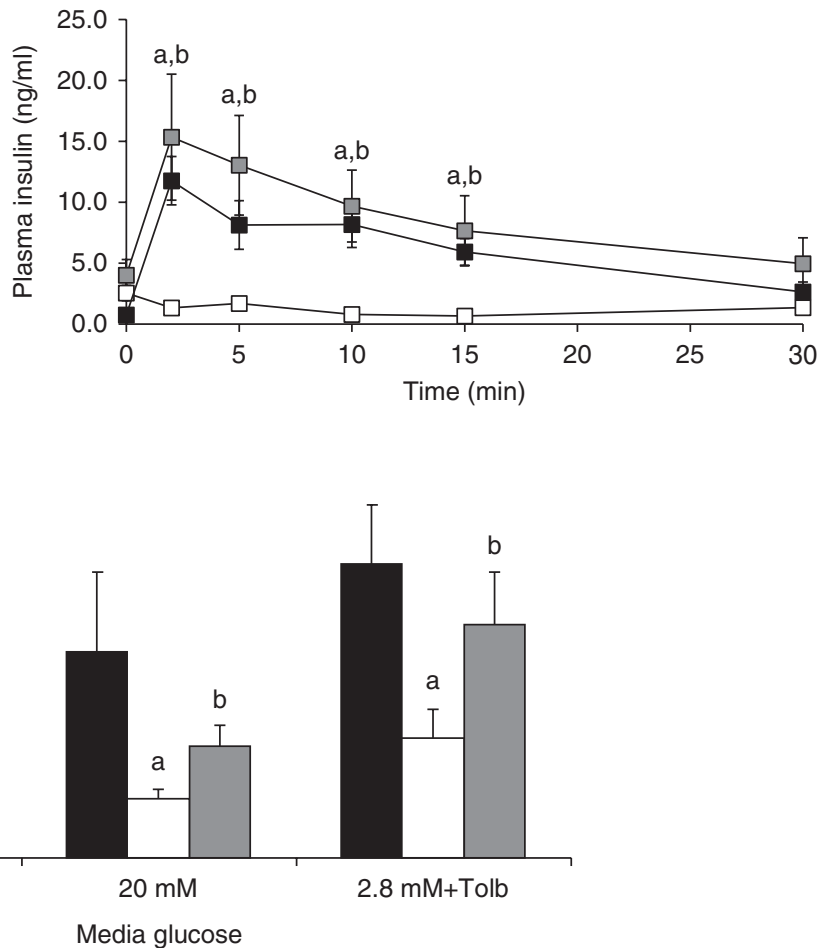

Figure $\mathbf{5}$

Change in plasma insulin following an IVTT to (A) glucose $(1 \mathrm{~g} / \mathrm{kg})$; (B) arginine ( $2 \mathrm{~g} / \mathrm{kg})$ and (C) tolbutamide (20 mg/kg) in B6 (dark squares), NZO (open squares) and NZO transgenic (grey squares) mice and corresponding total area under curve for insulin in panel inset. (D) Change in plasma insulin following an IVTT to glucose in 1-year old B6

reverse the insulin secretory defect of the NZO mice, an IVTT to glucose was performed (Fig. 5). As can be seen in Fig. $5 \mathrm{~A}$, the expression of the $\mathrm{B} 6 \mathrm{Abcc} 8$ allele in the NZO mouse significantly improved early-phase glucosemediated insulin secretion (NZO transgenic: 13.9 \pm $2.5 \mathrm{ng} / \mathrm{ml} \times 5 \mathrm{~min} \quad$ vs $\quad \mathrm{NZO}: 2.4 \pm 1.4 \mathrm{ng} / \mathrm{ml} \times 5 \mathrm{~min}$ $(P<0.05)$ vs $\mathrm{B} 6: 8.5 \pm 1.6 \mathrm{ng} / \mathrm{ml} \times 5 \mathrm{~min}(P<0.05))$. When the total AUC for insulin was calculated (panel insert (dark squares), NZO (open squares) and NZO transgenic (grey squares) mice. (E) Insulin secretion from isolated islets from B6 (black bars), NZO (white bars) and NZO transgenic (grey bars) mice incubated with $2 \mathrm{mM}$ glucose, $20 \mathrm{mM}$ glucose or $2 \mathrm{mM}$ glucose plus $200 \mathrm{mM}$ tolbutamide for $60 \mathrm{~min}$. Values are presented as mean \pm s.E.M. $n=4-8$. ${ }^{\mathrm{a}} P<0.05$ vs B6, ${ }^{\mathrm{b}} \boldsymbol{P}<0.05$ vs NZO.

Fig. 5A), the NZO transgenic mice secreted significantly more insulin than NZO mice $(P<0.05)$, and similar to B6.

To further define the molecular basis of the $A b c c 8$ defect, we investigated the response to the non-glucose secretagogue, arginine, which acts to secrete insulin by direct depolarisation of the $\beta$-cell membrane, and the sulphonylurea, tolbutamide. Both the NZO transgenic and NZO mice had significantly higher total AUC for insulin

Published by Bioscientifica Ltd. 
A

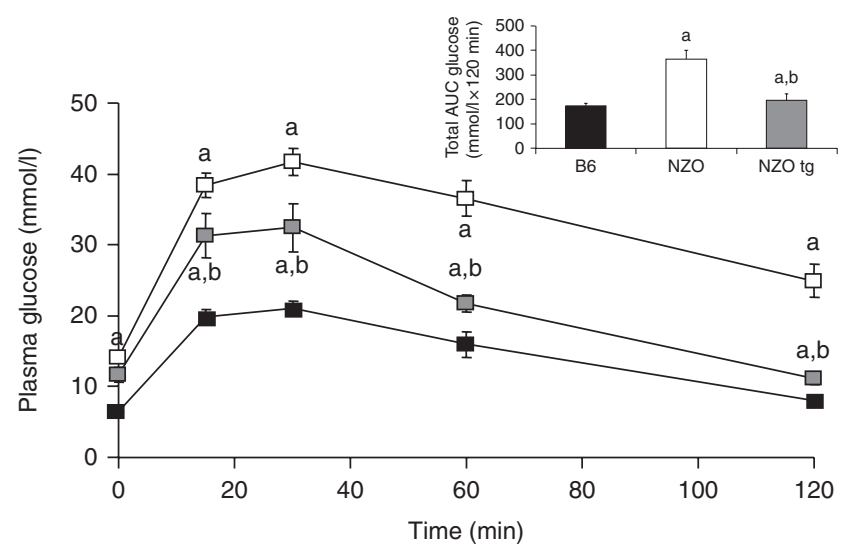

Figure 6

(A) Plasma glucose levels following an IPGTT (1 $\mathrm{g} / \mathrm{kg}$ ) in B6 (black squares), NZO (white squares) and NZO transgenic (grey squares) mice and corresponding total area under curve for glucose in panel inset $\left({ }^{\mathrm{a}} P<0.05\right.$ NZO transgenic vs B6 and ${ }^{\mathrm{b}} P<0.05$ NZO vs B6) (B) Plasma glucose levels

compared with the $\mathrm{B} 6$ mice following arginine stimulation (Fig. 5B). As expected, following tolbutamide administration, the NZO mice did not secrete adequate amounts of insulin compared with B6 mice and this was reflected in the significant reduction in total AUC for insulin (Fig. 5C, $P<0.05$ ). Conversely, the NZO transgenic mice demonstrated higher secretion at the 2 min timepoint only and total AUC for insulin was also significantly greater compared to NZO mice (Fig. 5C). Even at one year of age, B6 and NZO transgenic mice were secreting significantly more insulin in response to glucose compared with NZO mice (Fig. 5D). In vitro assessment in isolated islets from NZO mice demonstrated defective insulin secretion compared to B6 islets in response to both high glucose and tolbutamide stimulation that was corrected in NZO transgenic islets (Fig. 5E). Therefore, expression of the B6 Abcc8/Kncj11 gene in the NZO mouse did not have an effect on arginine-induced insulin stimulation but improved secretion following glucose and tolbutamide stimulation. Taken together, these data suggest that $A b c c 8 / K c n j 11$ is partly responsible for the defect in early-phase glucosemediated insulin secretion in the NZO mouse.

\section{Glucose tolerance and insulin sensitivity in NZO transgenic mice}

Since there was improved insulin secretory function in the NZO transgenic mice expressing the functional $A b c c 8 / K c n j 11$ gene, we investigated whether glucose

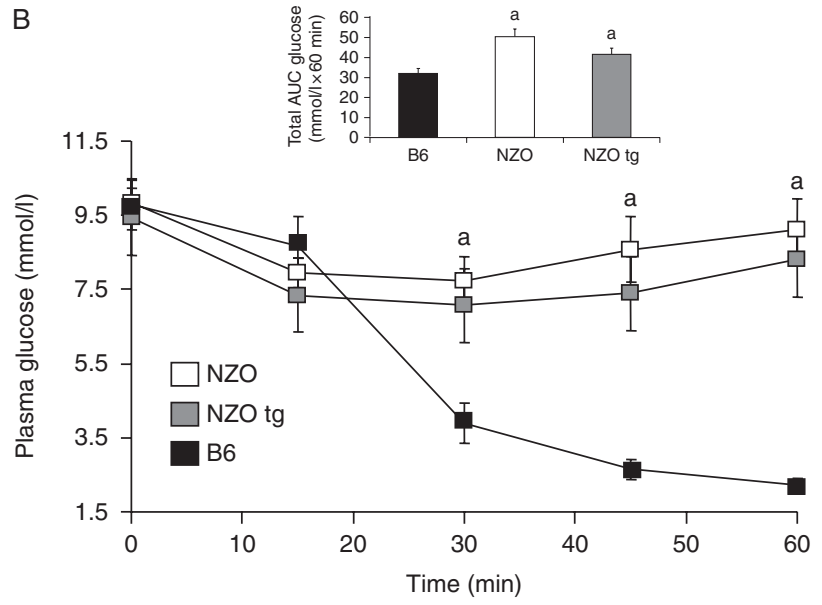

following an ITT (0.5 IU/kg) in B6 (black squares), NZO (white squares) and NZO transgenic mice (grey squares) and corresponding total area under curve for glucose in panel inset ( ${ }^{\mathrm{a}} P<0.05 \mathrm{NZO}$ transgenic vs $\left.\mathrm{B} 6\right)$. Values are presented as mean \pm s.E.M. $n=8-10$. ${ }^{\text {a }} P<0.05$ vs $B 6,{ }^{b} P<0.05$ vs NZO.

tolerance could also be enhanced in these mice. Following an intraperitoneal glucose challenge (Fig. 6A), NZO mice were glucose intolerant compared with $\mathrm{B} 6$ mice whilst NZO transgenic mice displayed significantly lower plasma glucose levels compared with the NZO control mice, but were significantly higher than the B6 mice (as demonstrated by both the glucose excursion during the GTT and the total AUC for glucose, (Fig. 6A and panel insert)). Therefore complementing the defective gene in the NZO mice with the functional form improved glucose tolerance, but not to the level of the control $\mathrm{B} 6$ mice.

To determine if this improved glucose tolerance had an effect on insulin sensitivity, an ITT was performed in NZO transgenic, NZO and B6 control mice. Following the insulin challenge, the B6 mice clearly lowered their plasma glucose levels over the duration of the test (Fig. 6B), while NZO transgenic and NZO control mice maintained elevated plasma glucose levels. Therefore, complementing the $A b c c 8 / K c n j 11$ gene did not improve insulin sensitivity in the NZO mice.

\section{Discussion}

The purpose of this study was to understand the genetic basis of islet $\beta$-cell dysfunction in the NZO mouse. The present study provides evidence that the defect in glucose-mediated insulin secretion in the NZO mouse is strongly associated with a component of the KATP-channel, the sulphonylurea receptor SUR1,

Published by Bioscientifica Ltd 
encoded by the gene $A b c c 8$. The NZO $A b c c 8$ allele has a number of insertion/deletion events in its promoter region and a $211 \mathrm{bp}$ deletion in the transcript, resulting from excision of exons 33 and 34 . NZO pancreata showed an associated reduction in SUR1 expression levels, as evidenced both at 4 and 10 weeks of age. In contrast, compared with the B6 sequence, the Kcnj11 NZO allele had neither sequence differences nor alterations in expression levels. These genetic variants in the $A b c c 8$ NZO promoter region would be expected to result in altered expression of the transcript as we have shown. Interestingly expression of the WT version of $A b c c 8 / K c n j 11$ specifically enhanced the early- but not late phase insulin secretory response of the NZO mouse.

A key consequence of the changes in the NZO $A b c c 8$ allele, was an impairment in the $\beta$-cell's ability to secrete insulin, particularly to glucose or those stimuli that directly bind to the receptor complex such as the sulphonylureas. This defect was manifested as early as 4 weeks of age (Veroni et al. 1991) and became significantly worse with time. However, stimulation with the non-glucose secretagogue arginine, which acts to stimulate insulin secretion through direct depolarisation of the $\beta$-cell membrane past the KATP-channel, caused an exaggerated insulin secretory response in the NZO mice. This suggests that NZO mice do not have a generalised defect in insulin secretion, but instead their defect is limited to the early events following glucose stimulation and that $A b c c 8$ is required for glucose-mediated insulin secretion. The molecular mechanism by which the defect in Abcc8 results in reduced insulin secretion in the NZO mouse is not clear and requires further investigation. This finding, together with an increase in pancreatic insulin content, suggests that at least at age (10 weeks) the NZO mouse does not have a deficit in $\beta$-cell mass and that the defect in secretion is functional.

We also show that expression of the B6 Abcc8/Kcnj11 genes in the NZO mouse leads to significant improvements in insulin secretion in response to either glucose or in particular to the sulphonylurea, tolbutamide. Most interesting is that the transgenic NZO mice had a better glucose-mediated release of insulin compared with both the NZO and B6 controls. In contrast, the response to arginine was the same as in the NZO control mice. This improvement in insulin secretion did not arise from improvements in other T2D related phenotypes, such as their sensitivity to insulin or their propensity to gain weight, since the transgenic NZO mice remained insulin insensitive and obese like the NZO control mice. Furthermore, in the transgenic mice the functional improvement was in the early (first) phase of insulin secretion as there was no improvement in second-phase insulin. This finding indicates that i) the KATP channel plays a significant role in early-phase insulin secretion and ii) other genes need to be restored to correct $\beta$-cell dysfunction in this model. Studies in mice with complete deletions of SUR1 have shown defects in both first- and second-phase insulin secretion (Seghers et al. 2000, Nakazaki et al. 2002, Shiota et al. 2002). Furthermore, the response of the SUR1 null mice to non-glucose stimuli such as carbachol, TPA, amino acids, acetylcholine and IBMX was comparable with the control mice (Nakazaki et al. 2002, Doliba et al. 2004, Nenquin, et al. 2004), while the response to arginine was enhanced at basal $(1.7 \mathrm{mM})$ glucose but reduced at higher glucose levels in vitro (Shiota et al. 2005). Our study showed that NZO mice had a heightened response to arginine in vivo. In addition SUR1 null mice displayed euglycaemia that remained for much of their lives, and normoinsulinaemia seen after a 6-h fast (Shiota et al. 2002), which is contrary to our NZO mice which displayed both hyperglycaemia and hyperinsulinaemia. The maintenance of euglycaemia in the null mice was shown to occur by the enhanced response to cholinergic stimulation and the increased level of intracellular calcium in the $\beta$-cell (Shiota et al. 2002, Doliba et al. 2004). In the NZO mice, the hyperglycaemia could be accounted for by their obese and insulin resistant phenotype impacting on glycaemia. Thus, despite differences between these two mouse models, the common absence of a fully functional $A b c c 8$ allele can lead to impairments in glucose-mediated insulin responses.

The data presented here highlight the importance of the $A b c c 8$ gene in the predisposition to $\beta$-cell dysfunction and glucose intolerance, but not to insulin resistance and obesity. It is interesting to note that while expression of a functioning $A b c c 8 / K c n j 11$ significantly enhanced glucosemediated insulin secretion (particularly the early response), this resulted in improved but not normalised glucose tolerance. This would suggest that normalisation of both phases of insulin secretion in addition to improved insulin sensitivity are perhaps required to normalise glucose tolerance in this model.

In humans, certain $A b c c 8$ mutations have been associated with the insulin secretory disorder persistent hyperinsulinaemia-hypoglycaemia of infancy (PHHI) (Huopio et al. 2000). Hyperinsulinaemia can be a consequence of $A b c c 8$ mutations, which is in contrast to our findings of defective glucose-mediated insulin secretion that arises from the NZO $A b c c 8$ allele. Interestingly, some individuals in the families of those with PHHI

Published by Bioscientifica Ltd. 
may develop diabetes later in life, prompting suggestion of a new genetic sub-class of T2D with similar phenotypes of glucose intolerance, $\beta$-cell dysfunction and hyperglycaemia (Huopio et al. 2003). There is evidence for an association between the Kcnj11 and $A b c c 8$ genes with T2D (Barroso et al. 2003, Gloyn et al. 2003). Indeed it has been suggested that the T2D susceptible variants in the Kcnj11 and $A b c c 8$ genes result in a gain-of-function of the KATP channel (Hamming et al. 2009). While we do not yet know whether the genetic defect in $A b c c 8$ leads to a gainor loss-of-function of the KATP channel, the NZO mouse can be used to model the role of $A b c c 8$ defects in the physiological processes leading to impaired insulin secretory function.

Partial suppression of the KATP channels has been shown to result in insulin hypersecretion initially, which reverted to undersecretion and glucose intolerance following high fat feeding for 3 months (Remedi et al. 2004). Furthermore, chronic treatment of normal mice with sulphonylurea resulted in reduced insulin secretion and glucose intolerance (Remedi \& Nichols 2008). Interestingly, our study showed that glucose-mediated insulin secretion did not have any chronic deleterious effects because 1-year old transgenic NZO mice had a comparable insulin secretory profile to $\mathrm{B} 6$ control mice and much higher than NZO control mice. This suggests that in the NZO transgenic mouse enhanced insulin secretion is chronically preserved, supporting the notion that in vivo chronic hyperexcitability does not lead to $\beta$-cell death (Nichols \& Remedi 2012).

In conclusion, we have demonstrated the importance of the $A b c c 8$ gene as a causative factor in the $\beta$-cell dysfunction displayed by the NZO mouse. Our study suggests that complementation of the $A b c c 8$ gene can enhance the early phase of glucose-mediated insulin secretion in the NZO mouse and leads to improved glucose tolerance.

\section{Supplementary data}

This is linked to the online version of the paper at http://dx.doi.org/10.1530/ JOE-15-0290.

\section{Declaration of interest}

The authors declare that there is no conflict of interest that could be perceived as prejudicing the impartiality of the research reported.

\section{Funding}

This work was supported by a project grant from the National Health and Medical Research Council of Australia and the National Heart Foundation. S A was supported by a Biomedical Career Development Award and Senior
Research Fellowship from the National Health and Medical Research Council of Australia. L B and G M are supported by a Program grant from the National Health and Medical Research Council of Australia (516700) and by the Diabetes Research Foundation of W A (Inc).

\section{Author contribution statement}

A H, S V, Z R, M S, C N J, M C, L B contributed to research data. $J \mathrm{P}$ contributed to concept design, discussion, and reviewed/edited the manuscript. A W T contributed to concept design, research data and discussion. S A, B C F, G M contributed to concept design, research data, discussion, and wrote and edited the manuscript.

\section{Acknowledgements}

We thank Jenny Davis (Department of Medicine (RMH) University of Melbourne) and Amy Blair (Department of Medicine (AH) University of Melbourne) for excellent technical assistance.

\section{References}

Andrikopoulos S 2010 Obesity and type 2 diabetes: slow down! - Can metabolic deceleration protect the islet beta cell from excess nutrientinduced damage? Molecular and Cellular Endocrinology 316 140-146. (doi:10.1016/j.mce.2009.09.031)

Andrikopoulos S, Massa CM, Aston-Mourney K, Funkat A, Fam BC, Hull RL, Kahn SE \& Proietto J 2005 Differential effect of inbred mouse strain (C57BL/6, DBA/2, 129T2) on insulin secretory function in response to a high fat diet. Journal of Endocrinology 187 45-53. (doi:10.1677/joe.1. 06333)

Andrikopoulos S, Blair AR, Deluca N, Fam BC \& Proietto J 2008 Evaluating the glucose tolerance test in mice. American Journal of Physiology. Endocrinology and Metabolism 295 E1323-E1332. (doi:10.1152/ajpendo. 90617.2008)

Ashcroft FM 2005 ATP-sensitive potassium channelopathies: focus on insulin secretion. Journal of Clinical Investigation 115 2047-2058. (doi:10.1172/JCI25495)

Aston-Mourney K, Wong N, Kebede M, Zraika S, Balmer L, McMahon JM, Fam BC, Favaloro J, Proietto J, Morahan G et al. 2007 Increased nicotinamide nucleotide transhydrogenase levels predispose to insulin hypersecretion in a mouse strain susceptible to diabetes. Diabetologia 50 2476-2485. (doi:10.1007/s00125-007-0814-x)

Barroso I, Luan J, Middelberg RP, Harding AH, Franks PW, Jakes RW, Clayton D, Schafer AJ, O'Rahilly S \& Wareham NJ 2003 Candidate gene association study in type 2 diabetes indicates a role for genes involved in $\beta$-cell function as well as insulin action. PLoS Biology $\mathbf{1}$ E20. (doi:10.1371/journal.pbio.0000020)

Cheng K, Andrikopoulos S \& Gunton JE 2013 First phase insulin secretion and type 2 diabetes. Current Molecular Medicine 13 126-139. (doi:10.2174/1566524011307010126)

Doliba NM, Qin W, Vatamaniuk MZ, Li C, Zelent D, Najafi H, Buettger CW, Collins HW, Carr RD, Magnuson MA et al. 2004 Restitution of defective glucose-stimulated insulin release of sulfonylurea type 1 receptor knockout mice by acetylcholine. American Journal of Physiology. Endocrinology and Metabolism 286 E834-E843. (doi:10.1152/ajpendo.00292.2003)

Fam BC, Andrikopoulos S. 2007 The New Zealand obese mouse: polygenic model of obesity, glucose intolerance and the metabolic syndrome. In Animal Models of Diabetes, Second Edition: Frontiers in Research, pp 139-158. Ed E Shafrir.

Funkat A, Massa CM, Jovanovska V, Proietto J \& Andrikopoulos S 2004 Metabolic adaptations of three inbred strains of mice (C57BL/6, DBA/2, and 129T2) in response to a high-fat diet. Journal of Nutrition 134 3264-3269. 
Giesen K, Plum L, Kluge R, Ortlepp J \& Joost HG 2003 Diet-dependent obesity and hypercholesterolemia in the New Zealand obese mouse: identification of a quantitative trait locus for elevated serum cholesterol on the distal mouse chromosome 5. Biochemical and Biophysical Research Communications 304 812-817. (doi:10.1016/S0006291X(03)00664-8)

Gloyn AL, Weedon MN, Owen KR, Turner MJ, Knight BA, Hitman G, Walker M, Levy JC, Sampson M, Halford S et al. 2003 Large-scale association studies of variants in genes encoding the pancreatic $\beta$-cell KATP channel subunits Kir6.2 (KCNJ11) and SUR1 (ABCC8) confirm that the KCNJ11 E23K variant is associated with type 2 diabetes. Diabetes 52 568-572. (doi:10.2337/diabetes.52.2.568)

Halter JB, Ward WK, Porte D Jr, Best JD \& Pfeifer MA 1985 Glucose regulation in non-insulin-dependent diabetes mellitus. Interaction between pancreatic islets and the liver. American Journal of Medicine 79 6-12. (doi:10.1016/0002-9343(85)90579-0)

Hamming KS, Soliman D, Matemisz LC, Niazi O, Lang Y, Gloyn AL \& Light PE 2009 Coexpression of the type 2 diabetes susceptibility gene variants KCNJ11 E23K and ABCC8 S1369A alter the ATP and sulfonylurea sensitivities of the ATP-sensitive $\mathrm{K}^{(+)}$channel. Diabetes $\mathbf{5 8}$ 2419-2424. (doi:10.2337/db09-0143)

Huopio H, Reimann F, Ashfield R, Komulainen J, Lenko HL, Rahier J, Vauhkonen I, Kere J, Laakso M, Ashcroft F et al. 2000 Dominantly inherited hyperinsulinism caused by a mutation in the sulfonylurea receptor type 1. Journal of Clinical Investigation 106 897-906. (doi:10.1172/JCI9804)

Huopio H, Otonkoski T, Vauhkonen I, Reimann F, Ashcroft FM \& Laakso M 2003 A new subtype of autosomal dominant diabetes attributable to a mutation in the gene for sulfonylurea receptor 1. Lancet 361 301-307. (doi:10.1016/S0140-6736(03)12325-2)

Kahn SE 2003 The relative contributions of insulin resistance and $\beta$-cell dysfunction to the pathophysiology of Type 2 diabetes. Diabetologia 46 3-19. (doi:10.1007/s00125-003-1190-9)

Kluge R, Giesen K, Bahrenberg G, Plum L, Ortlepp JR \& Joost HG 2000 Quantitative trait loci for obesity and insulin resistance (Nob1, Nob2) and their interaction with the leptin receptor allele (LeprA720T/T1044I) in New Zealand obese mice. Diabetologia 43 1565-1572. (doi:10.1007/s001250051570)

Kluth O, Mirhashemi F, Scherneck S, Kaiser D, Kluge R, Neschen S, Joost HG \& Schurmann A 2011 Dissociation of lipotoxicity and glucotoxicity in a mouse model of obesity associated diabetes: role of forkhead box O1 (FOXO1) in glucose-induced beta cell failure. Diabetologia 54 605-616. (doi:10.1007/s00125-010-1973-8)

Kooptiwut S, Kebede M, Zraika S, Visinoni S, Aston-Mourney K, Favaloro J, Tikellis C, Thomas MC, Forbes JM, Cooper ME et al. 2005 High glucoseinduced impairment in insulin secretion is associated with reduction in islet glucokinase in a mouse model of susceptibility to islet dysfunction. Journal of molecular endocrinology 35 39-48. (doi:10.1677/jme.1.01720)

Lamont BJ, Visinoni S, Fam BC, Kebede M, Weinrich B, Papapostolou S, Massinet H, Proietto J, Favaloro J \& Andrikopoulos S 2006 Expression of human fructose-1,6-bisphosphatase in the liver of transgenic mice results in increased glycerol gluconeogenesis. Endocrinology 147 2764-2772. (doi:10.1210/en.2005-1498)

Lander E \& Kruglyak L 1995 Genetic dissection of complex traits: guidelines for interpreting and reporting linkage results. Nature Genetics 11 241-247. (doi:10.1038/ng1195-241)

Larkins RG \& Martin FI 1972 Selective defect in insulin release in one form of spontaneous laboratory diabetes. Nature 235 86-88. (doi:10.1038/ 235086a0)

Leiter EH, Reifsnyder PC, Flurkey K, Partke HJ, Junger E \& Herberg L 1998 NIDDM genes in mice: deleterious synergism by both parental genomes contributes to diabetogenic thresholds. Diabetes 47 1287-1295. (doi:10.2337/diab.47.8.1287)

Morahan G, Brugliera M \& Cox KO 1989 A rapid and economical method for screening transgenic mice. Nucleic Acids Research 173608. (doi:10.1093/nar/17.9.3608)
Nakazaki M, Crane A, Hu M, Seghers V, Ullrich S, Aguilar-Bryan L \& Bryan J 2002 cAMP-activated protein kinase-independent potentiation of insulin secretion by cAMP is impaired in SUR1 null islets. Diabetes $\mathbf{5 1}$ 3440-3449. (doi:10.2337/diabetes.51.12.3440)

Nenquin M, Szollosi A, Aguilar-Bryan L, Bryan J \& Henquin JC 2004 Both triggering and amplifying pathways contribute to fuel-induced insulin secretion in the absence of sulfonylurea receptor- 1 in pancreatic $\beta$-cells. Journal of Biological Chemistry 279 32316-32324. (doi:10.1074/jbc. M402076200)

Nichols CG \& Remedi MS 2012 The diabetic $\beta$-cell: hyperstimulated vs. hyperexcited. Diabetes, Obesity \& Metabolism 14(Suppl 3) 129-135. (doi:10.1111/j.1463-1326.2012.01655.x)

Palmer ND, Lehtinen AB, Langefeld CD, Campbell JK, Haffner SM, Norris JM, Bergman RN, Goodarzi MO, Rotter JI \& Bowden DW 2008 Association of TCF7L2 gene polymorphisms with reduced acute insulin response in Hispanic Americans. Journal of Clinical Endocrinology and Metabolism 93 304-309. (doi:10.1210/jc.2007-1225)

Plum L, Kluge R, Giesen K, Altmuller J, Ortlepp JR \& Joost HG 2000 Type 2 diabetes-like hyperglycemia in a backcross model of NZO and SJL mice: characterization of a susceptibility locus on chromosome 4 and its relation with obesity. Diabetes 49 1590-1596. (doi:10.2337/diabetes. 49.9.1590)

Plum L, Giesen K, Kluge R, Junger E, Linnartz K, Schurmann A, Becker W \& Joost HG 2002 Characterisation of the mouse diabetes susceptibilty locus Nidd/SJL: islet cell destruction, interaction with the obesity QTL Nob1, and effect of dietary fat. Diabetologia 45 823-830. (doi:10.1007/ s00125-002-0796-7)

Reifsnyder PC \& Leiter EH 2002 Deconstructing and reconstructing obesity-induced diabetes (diabesity) in mice. Diabetes 51 825-832. (doi:10.2337/diabetes.51.3.825)

Reifsnyder PC, Churchill G \& Leiter EH 2000 Maternal environment and genotype interact to establish diabesity in mice. Genome Research 10 1568-1578. (doi:10.1101/gr.147000)

Remedi MS \& Nichols CG 2008 Chronic antidiabetic sulfonylureas in vivo: reversible effects on mouse pancreatic $\beta$-cells. PLoS Medicine 5 e206. (doi:10.1371/journal.pmed.0050206)

Remedi MS, Koster JC, Markova K, Seino S, Miki T, Patton BL, McDaniel ML $\&$ Nichols CG 2004 Diet-induced glucose intolerance in mice with decreased $\beta$-cell ATP-sensitive $\mathrm{K}^{+}$channels. Diabetes 53 3159-3167. (doi:10.2337/diabetes.53.12.3159)

Saxena R, Voight BF, Lyssenko V, Burtt NP, de Bakker PI, Chen H, Roix JJ, Kathiresan S, Hirschhorn JN, Daly MJ et al. 2007 Genome-wide association analysis identifies loci for type 2 diabetes and triglyceride levels. Science 316 1331-1336. (doi:10.1126/science.1142358)

Scherneck S, Nestler M, Vogel H, Bluher M, Block MD, Berriel Diaz M, Herzig S, Schulz N, Teichert M, Tischer S et al. 2009 Positional cloning of zinc finger domain transcription factor Zfp69, a candidate gene for obesity-associated diabetes contributed by mouse locus Nidd/SJL. PLoS Genetics 5 e1000541. (doi:10.1371/journal.pgen.1000541)

Seghers V, Nakazaki M, DeMayo F, Aguillar-Bryan L \& Bryan J 2000 Sur1 knockout mice. A model for KATP channel-independent regulation of insulin secretion. Journal of Biological Chemistry $2759270-9277$. (doi:10.1074/jbc.275.13.9270)

Shiota C, Larsson O, Shelton KD, Shiota M, Efanov AM, Hoy M, Lindner J, Kooptiwut S, Juntti-Berggren L, Gromada J et al. 2002 Sulfonylurea receptor type 1 knock-out mice have intact feeding-stimulated insulin secretion despite marked impairment in their response to glucose. Journal of Biological Chemistry 277 37176-37183. (doi:10.1074/jbc. M206757200)

Shiota C, Rocheleau JV, Shiota M, Piston DW \& Magnuson MA 2005 Impaired glucagon secretory responses in mice lacking the type 1 sulfonylurea receptor. American Journal of Physiology. Endocrinology and Metabolism 289 E570-E577. (doi:10.1152/ajpendo.00102.2005)

Sladek R, Rocheleau G, Rung J, Dina C, Shen L, Serre D, Boutin P, Vincent D, Belisle A, Hadjadj S et al. 2007 A genome-wide association study 
identifies novel risk loci for type 2 diabetes. Nature $\mathbf{4 4 5} 881-885$ (doi:10.1038/nature05616)

Taylor BA, Wnek C, Schroeder D \& Phillips SJ 2001 Multiple obesity QTLs identified in an intercross between the NZO (New Zealand obese) and the SM (small) mouse strains. Mammalian Genome 12 95-103. (doi:10.1007/s003350010254)

Veroni MC, Proietto J \& Larkins RG 1991 Evolution of insulin resistance in New Zealand obese mice. Diabetes 40 1480-1487. (doi:10.2337/diab.40. 11.1480)

Visinoni S, Fam BC, Blair A, Rantzau C, Lamont BJ, Bouwman R, Watt MJ, Proietto J, Favaloro JM \& Andrikopoulos S 2008 Increased glucose production in mice overexpressing human fructose-1,6-bisphosphatase in the liver. American Journal of Physiology. Endocrinology and Metabolism 295 E1132-E1141. (doi:10.1152/ajpendo.90552.2008)
Vogel H, Nestler M, Ruschendorf F, Block MD, Tischer S, Kluge R, Schurmann A, Joost HG \& Scherneck S 2009 Characterization of Nob3, a major quantitative trait locus for obesity and hyperglycemia on mouse chromosome 1. Physiological Genomics 38 226-232. (doi:10.1152/physiolgenomics.00011.2009)

Wong N, Blair AR, Morahan G \& Andrikopoulos S 2010 The deletion variant of nicotinamide nucleotide transhydrogenase (Nnt) does not affect insulin secretion or glucose tolerance. Endocrinology 151 96-102. (doi:10.1210/en.2009-0887)

Zraika S, Aston-Mourney K, Laybutt DR, Kebede M, Dunlop ME, Proietto J \& Andrikopoulos S 2006 The influence of genetic background on the induction of oxidative stress and impaired insulin secretion in mouse islets. Diabetologia 49 1254-1263. (doi:10.1007/ s00125-006-0212-9)

Received in final form 14 October 2015

Accepted 22 October 2015

Accepted Preprint published online 22 October 2015
Published by Bioscientifica Ltd. 